\title{
Nicholas Callan - priest, professor and scientist
}

\author{
Rev. M.T. Casey, O.P., M.Sc., Ph.D., F.I.C.I. \\ Indexing terms: History, Electromagnetics, Batteries and cells, Motors
}

\begin{abstract}
Nicholas Callan (1799-1864) was an Irish priest and scientist who, although his name has been largely forgotten by historians, was a pioneer of electrical science. He invented the induction coil some fifteen years before Ruhmkorff, to whom credit is usually given. He developed some very practical batteries and also experimented with crude forms of electric lighting. Callan was also a very saintly man, donating a large part of his professor's salary for the relief of the poor. In the words of his obituary: 'His extraordinary piety, his perfect simplicity and unaffected candour endeared him to everyone who knew him'.
\end{abstract}

\section{Introduction}

Nicholas Joseph Callan, whose portrait is shown in Fig. 1, was an Irish priest and scientist of the first half of the nineteenth century. He was Professor of Natural Philosophy

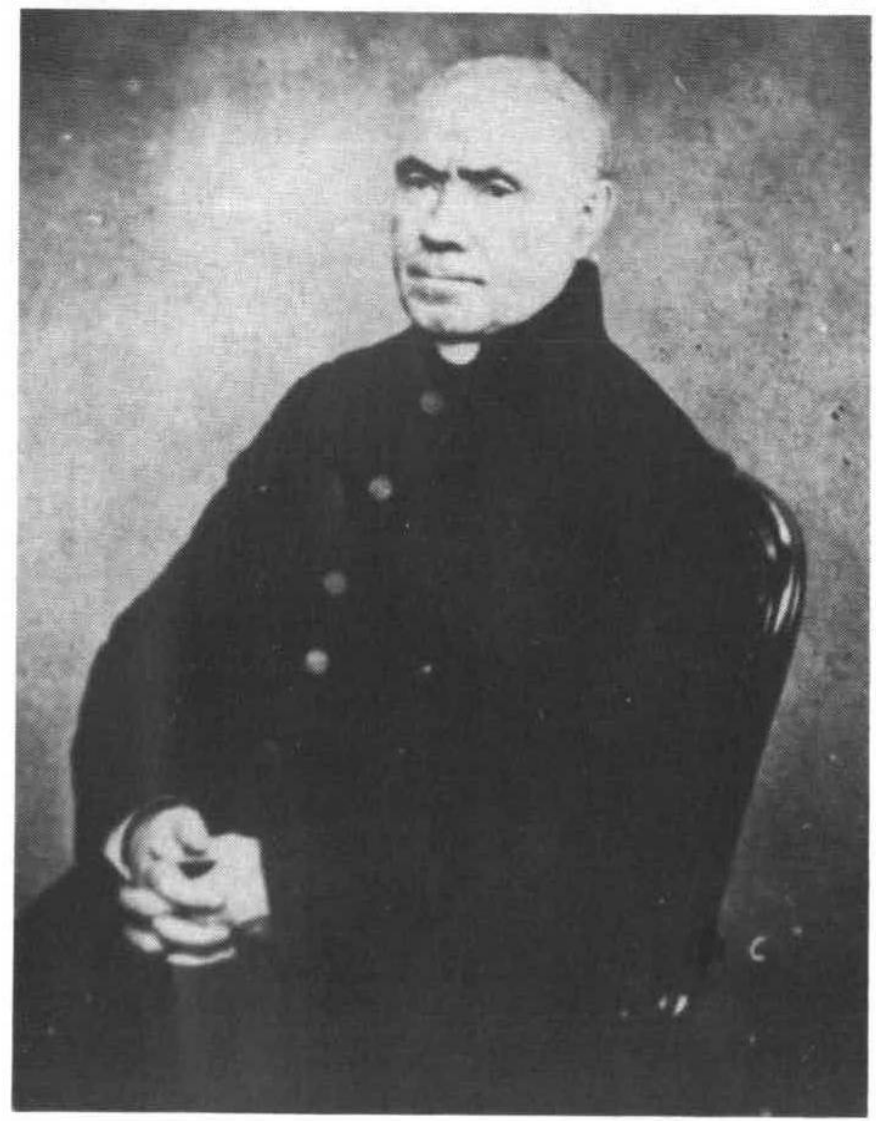

Fig. 1 The Reverend Nicholas Joseph Callan, D.D., 1799-1864.

Professor of Natural Philosophy at St. Patrick's College Maynooth, 1826-1864

at Maynooth College from 1826 to 1864 and was a pioneer in electrical science. He constructed great batteries, electromagnets and electric motors, and he invented the induction coil in 1836, his great coil of 1837 being capable of

Paper 4219A (S7), received 11th February 1985

The author is Curator of the Museum, St. Patrick's College, Maynooth, Co Kildare, Republic of Ireland

This paper was originally delivered as a tape-recorded lecture at Savoy Place. A transcript of the tape was made by Dr. A.F. Anderson, and it was prepared for publication by Dr. V.J. Phillips producing fifteen-inch $(38 \mathrm{~cm})$ sparks. In spite of this, his name has hitherto found little or no place in works devoted to the history of science and technology and credit for his discoveries and inventions has often been given to others. Ruhmkorff has been give the credit for the induction coil.

A few authors have remembered his contributions and have saved his name and reputation from total oblivion, notably the late Mgr. McLaughlin, himself a successor of Callan in the Chair of Natural Philosophy and Experimental Physics, and Vice-President of Maynooth College, the result of whose painstaking research on Callan was published in 1965 [1,2]. Some years earlier, in 1957, Mr. John D. Gallivan read a paper on Callan at a meeting of the British Association for the Advancement of Science in Dublin, and this paper was reported in the October number of Nature for that year [3]. It is interesting to note that at an earlier meeting of the British Association held in Dublin in 1857, Callan himself read a paper asserting his priority in the invention of the induction coil $[4,5]$. J.A. Fleming, in his books on 'The alternating current transformer in theory and practice', published in London in 1889 and 1892 [6], devoted several pages to the description and illustration of various Callan induction coils and, in his article on the induction coil in the 11th edition of the Encyclopaedia Britannica [7], he gave Callan full credit for its invention.

Callan was born on the 22nd December 1799 at Darver, between Drogheda and Dundalk in County Louth. The Callans were a well-to-do family of considerable repute in the district. They farmed extensively and, in addition, were bakers, maltsters and brewers. One of them, Phillip Callan, was elected to Parliament about the Parnellite period. Nicholas was the fifth son of a family of seven. He received his early education at Dundalk Academy under the Rev. William Neilson, a Presbyterian clergyman who enjoyed a high reputation as a classical scholar and teacher. Having completed his education in Dundalk, Callan was sent to Navan Seminary to do his initial preparation for the priesthood and, in 1816, he entered the National Seminary at Maynooth. He matriculated into the Class of Rhetoric where he read advanced courses in Latin, Greek and English for two years. During his third year he studied Experimental and Natural Philosophy under the guidance of Dr. Cornelius Denvir, later Bishop of Down and Connor, who exerted a big influence on him. Denvir was the first to introduce the experimental method into his teaching. He was also interested in magnetism, and his 
influence largely determined the direction of Callan's future researches. As Mgr. McLaughlin prettily puts it: 'Denvir was the flint that struck the first spark of scientific inquisitiveness from the Callan steel' [1]. Callan finished that year high up in the prize lists which show Nicolaus Callan Armacanus in the first premium block in the subject of 'Mathesios et Philosophia Naturalis'.

Having completed his literary and scientific studies, Callan now entered the Divinity School where, for three more years, he read Dogma and Moral Theology, Sacred Scripture and Canon Law and, on completion of his ordinary theological course in 1822 , he was elected to a studentship on the Dunboyne Establishment, set up to enable the more distinguished students to engage in higher studies. He was ordained priest on 24th May 1823 and, by his early ordination in his 24 th year, he forfeited a considerable legacy to which was attached the stipulation that he should not take priestly orders until he was 26 years old. On completion of his studies in 1824 he was sent to Rome, where he attended lectures in the Sapienza University and obtained a Doctorate in Divinity in 1826 During his stay in Rome he became acquainted with the works of Galvani and Volta. On the resignation of $\mathrm{Dr}$ Denvir, his former Professor, he applied for the Chair and, after the Concursus of 1826 , he was appointed to it by the Trustees on 15th September 1826. The college at Maynooth had been founded in 1795 by the Irish Parliament, for the education of Catholic Clergy. Prior to that date clerics were educated in various Irish colleges on the continent. During the revolutionary period it was feared that Irish students going to these colleges would imbibe 'pernicious revolutionary ideas', and so the government thought it better that they should be educated at home. The Trustees, 21 in all, were appointed by the government and comprised the Lord Chancellor as Chairman, with three high-ranking statesmen, the four Catholic Archbishops, three Bishops, three Catholic Peers with two Baronets, Rev. Dr. Hussey, the first President, and three laymen. There were ten Professorial Chairs in the College and Professors had to undergo a 'concursus' or public examination before appointment. The Chair of 'Natural and Experimental Philosophy' to which Callan was appointed embraced mathematics, mechanics, astronomy, and such experimental sciences as existed at that period.

With characteristic ardour, the new Professor embarked on his task of teaching. For texts, he used Darré's Treatise on Geometry and Trigonometry, which he incorporated into his own 'Praelectiones'. Part 1 of these 'Praelectiones' deals with conic sections, mechanics and optics. Part 2 is a clear introduction to practical astronomy. Like Newton himself in his 'Principia', Callan employs a good deal of Euclidean style of definition and demonstration. A special section is devoted to the systems of the world, from the Ptolomaic to the Copernican, the merits and demerits of each being argued out. Kepler's laws and the work of Tycho Braché come in for particular mention and study. This 'Gentleman's Course', inaugurated and developed by Callan, remained an integral part of the Maynooth curriculum until 1910, when the college came under the National University of Ireland.

However, it was in the field of electricity that Callan showed his real inventive genius. To appraise his researches in these fields, it will be of advantage to consider them under various headings, all closely interrelated, but not in chronological order, since many of his researches were undertaken simultaneously. We shall take them in the following sequence: electromagnets and the induction coil; electric motors; and batteries.
With the advent of batteries, it was soon discovered that a coil of wire carrying a current became magnetic, and the coil, when wrapped around an iron bar, rendered it magnetic [8]. In England, Sturgeon and Faraday constructed powerful electromagnets, and so did Callan. Several of them are still kept in the Maynooth College Museum. The great horseshoe magnet (Fig. 2) stands nearly six feet (2 m)

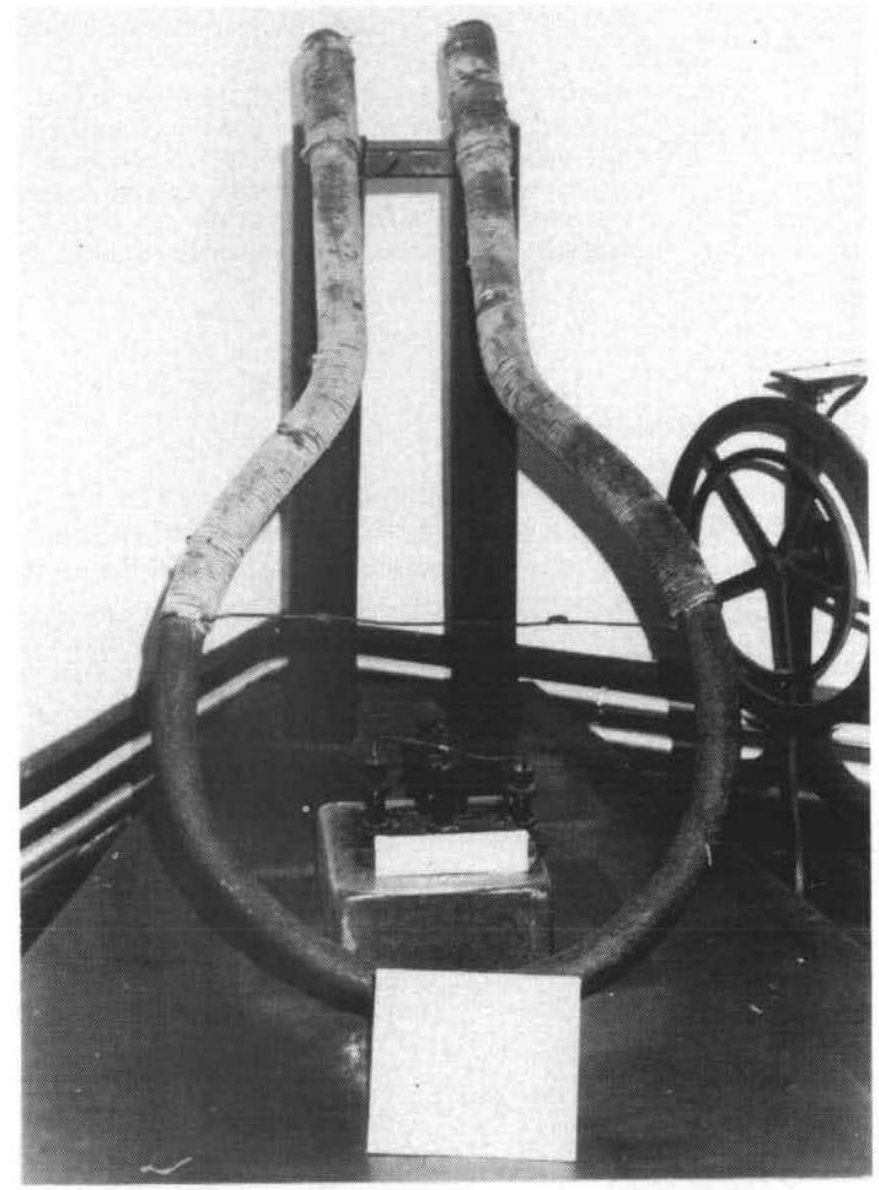

Fig. 2 Callan's large horse-shoe electromagnet; also, his 'repeater' mechanism

[Photo. courtesy Irish Electricity Supply Board]

in height and the diameter of the poles is about two and a half inches $(6.35 \mathrm{~cm})$. It weighs approximately two hundred and ten pounds $(9.5 \mathrm{~kg}$ ) and the iron work was done by James Briody, the village blacksmith. Callan wound heavy copper wire, insulated by wrapping tape around it, on the poles; this was in the late 1820s long before insulated wire came upon the market. (It was the Henley Company who first manufactured insulated wire in any quantity in about 1838 or 1839 [9].) This huge electromagnet of Callan's had a lifting power of some two tons when supplied with current from his battery. He constructed several electromagnets varying in length and shape and used them for testing his batteries; the greater the lifting power, the better the battery. He was influenced by the work of Henry [10] and Page [11] in America, who independently discovered self-induction by interrupting the current flowing through a spiral of copper ribbon. They felt a slight shock if the ends of the ribbon were held in the hands. Callan introduced copper wire in place of the ribbon of Henry and Page and, more importantly, he wound the wire, insulated with tape, on an iron core and obtained shocks of greater intensity [5, 12]. Fig. 3 shows a selection of Callan's coils. In one of his first coils he wound two 
lengths of copper wire, each two hundred feet $(61 \mathrm{~m})$ long, around a straight iron bar of one inch $(2.54 \mathrm{~cm})$ diameter.

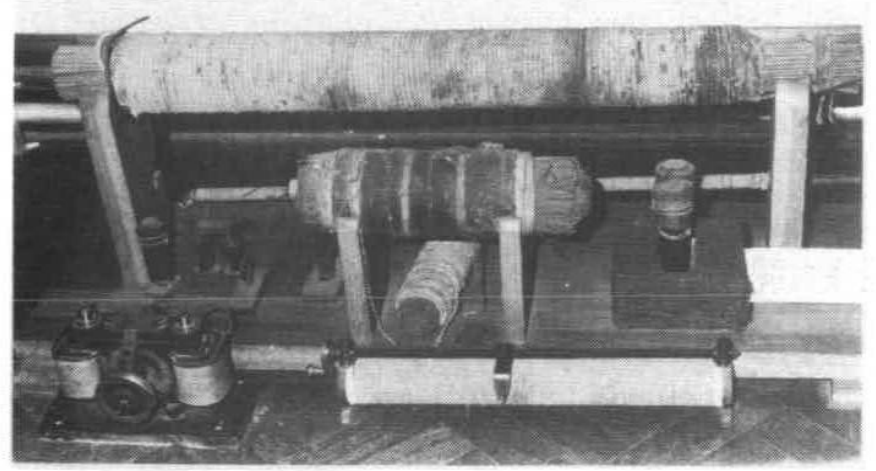

Fig. 3 A selection of Callan's coils

[Photo. courtesy Irish Electricity Supply Board]

The two windings were joined in series but the current was sent only through one winding, whilst the shock was taken from the full four-hundred feet $(122 \mathrm{~m})$ of coil; i.e. it was an auto-transformer' arrangement. Used with one of his cells, this apparatus gave shocks of great intensity. In fact, he used this as one method of testing the power of his batteries. He persuaded his students to take shocks from it, and from the reactions of the students, he judged the power of the cell (a rather original procedure, one must admit), and he tells us naively that with fourteen Wollaston cells the shock was so strong that the person who received it felt the effects for some days! He also adds that, with sixteen coils, nobody could be persuaded to take the shock [13]. There is a story that one student named William Walsh, who later became Archbishop of Dublin, was rendered unconscious by a shock [1].

Callan was the first to recognise (circa 1836) that the intensity of the shock depended on the rapidity of the break in the circuit. He constructed an ingenious device, which can be seen in Fig. 4 and also in Fig. 2, for interrupting the current extremely rapidly (2000 to 3000 times

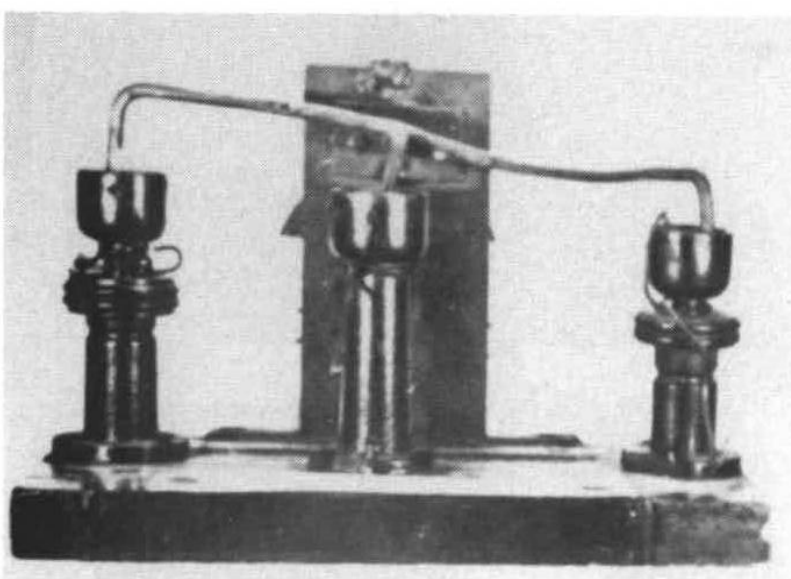

Fig. 4 Callan's interrupter or 'repeater'

per minute). It was made out of the escapement mechanism from a grandfather clock. He attached a crank handle to the escapement cog wheel and a thick copper bar to the rocker which dipped in and out of cups filled with mercury. On rotating the crank, he got more than fifty interruptions a second [14]. This device, which he referred to as a 'repeater', is still preserved in the College Museum. This is an important instrument in the history of the nature of electromagnetic induction, for it focused attention on the significance of the rapid change in magnetic flux.

In his next experiment, Callan used a primary coil of fifty feet $(15 \mathrm{~m})$ of thick copper wire and a secondary coil of thirteen hundred feet $(396 \mathrm{~m})$ of fine wire. In preliminary trials he sent the battery current through the primary and took the shock from both the primary and the secondary coils in series. His next step was to separate completely the primary and secondary coils. Thus Callan discovered for himself the principle of the step-up transformer of modern high-voltage electricity [15].

As a result of these experiments, he now had all the elements of the modern induction coil apart from the condenser. This was suggested some seventeen years later by Fizeau in the Comptes Rendus of 1853 [16]. Its function was to reduce the sparking in the primary circuit breaker. Callan improved the performance of his repeater by employing amalgamated copper contacts which dipped in and out of mercury, covered with a layer of oil to reduce oxidation. He found that the amalgamated copper contacts were superior to platinum ones. He also investigated various insulating materials for high-tension work and found that a mixture of beeswax and gutta-percha gave very good insulation. Its efficacy is shown by the enormous sparks, fifteen inches $(38 \mathrm{~cm})$ in length, which were obtained with his great induction coil of 1837 . In another of his coils, ten thousand feet $(3 \mathrm{~km})$ of fine iron wire were carefully insulated with this mixture and used as a secondary coil over an energising primary circuit consisting of seven parallel sections, each having seventy feet $(21 \mathrm{~m})$ of wire. With this formidable apparatus and his repeater he obtained secondary currents sufficient to strike an arc between the carbons in an arc lamp. No other experimenter got results in any way comparable at this time and Callan sent a replica of this apparatus to Sturgeon in London, who showed it to members of the London Electrical Society in August $1837[5,17]$.

A spate of induction coils immediately followed; Sturgeon's, Nesbitt's, Joule's, Page's, Bachhoffner's and others. It is quite clear from Sturgeon's Annals of Electricity where the stimulus for all this activity came from. Bachhoffner explicitly acknowledges his debt to Callan in Sturgeon's Annals in 1838 [12] and Sturgeon himself adopted Callan's exact specifications for the lengths of his windings.

Callan now built the 'medium' coil which is still preserved at the college (Fig. 5). It has as its core a bundle of thick iron wires and a primary coil of $6 \mathrm{~mm}$ diameter copper wire insulated by winding with tape. The secondary coil consists of several thousand feet of fine iron wire, $0.5 \mathrm{~mm}$ or less in diameter, insulated with his beeswax/ gutta-percha mixture. The diameter of the secondary coil was 18.5 inches $(47 \mathrm{~cm})$ and it was 4.25 inches $(10.8 \mathrm{~cm})$ thick. The diameter of the central opening which held the primary was 6 inches $(15 \mathrm{~cm})$. The make-and-break mechanism was the trembler system, the mechanism which is used in electric bells to this day, invented by J.W. McGaulay of Dublin, his contemporary.

The 'giant' coil, which can be seen in Fig. 6, followed in 1837 and this, too, is preserved at Maynooth. Its overall length is about five feet $(1.5 \mathrm{~m})$. The primary coil consists of thick copper wire, tape-insulated, wound around a core of iron rods about 40 inches $(1 \mathrm{~m})$ in length. There are three secondary coils, each one similar to that of the medium coil. These are said to contain about 150000 feet $(45.7 \mathrm{~km})$ of fine iron wire, all hand-insulated with the mixture. In an article in Electrician in 1891 [19, 20], J.A. Fleming stated that 'when supplied with current from six cells of the Maynooth battery, sparks fifteen inches long 
can still be obtained'. In fact, a fifteen-inch spark length was not exceeded until 1890 or later.

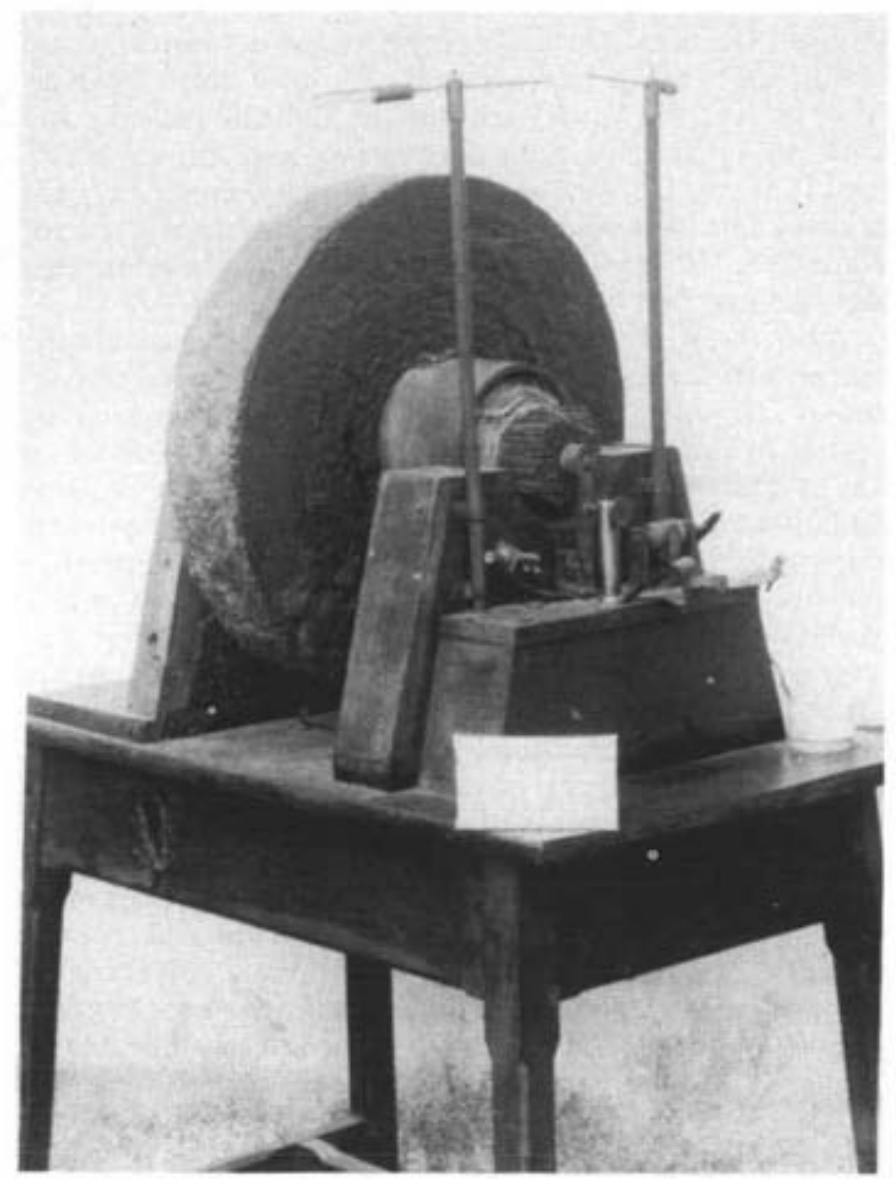

Fig. 5 Callan's 'medium' induction coil

In his address to the British Association meeting in Dublin in $1857[4,5]$, Callan made the following statement:

'It is now more than twenty years since I discovered the method of making the induction coil, or a coil by which an electric current of enormous intensity may be produced with the aid of a single galvanic cell; a coil which is now to be used for the working of the Atlantic Telegraph. Mr. Faraday was the first to develop the laws of electrical induction, but he did not discover the method of making a coil by which a current of very great intensity may be obtained by means of a very small battery. This was first discovered in Maynooth College in 1836. In the summer of 1837 , I sent to the late Mr. Sturgeon a small coil which he exhibited at a meeting of the Electrical Society in London and from which he gave shocks to several of the members.

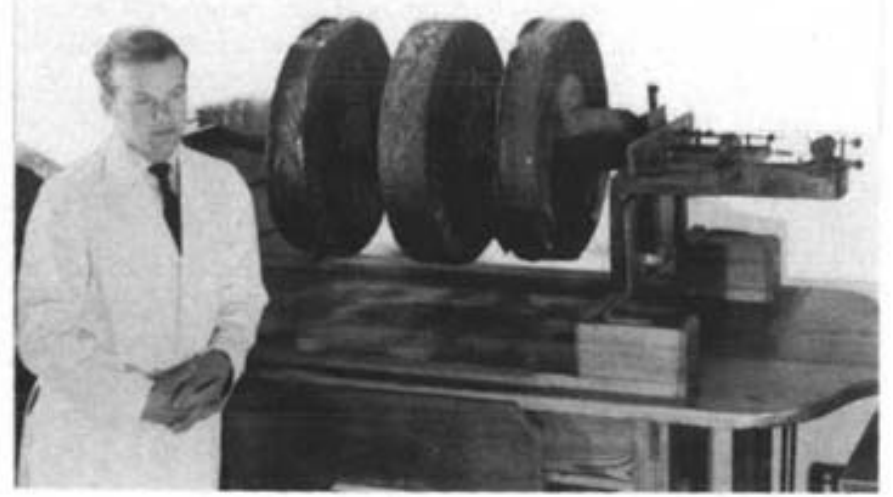

Fig. 6 The 'giant' induction coil
This was the first induction coil of great power seen outside the College of Maynooth. The first notice of the discovery of the coil is to be found in a paper of mine published in the London Philosophical Magazine for December 1836 [13]. In April 1837 [14], I published in Sturgeon's Annals of Electricity a description of an instrument which I devised for producing a rapid succession of electrical currents in the coil by rapidly making and breaking communication with the battery (i.e. his repeater); thus before April 1837 I had completed the coil as a machine for producing a regular supply of electricity. From 1837 to the end of 1854 , my attention was directed to other matters.'

Callan sent coils to various people: to Sturgeon as previously mentioned, to Lord Rosse and to Downside Abbey. Lord Rosse was President of the Royal Society and, after Callan's death, he wrote to Dr. Russell, the President of Maynooth College, stating that Callan was undoubtedly the first inventor of the induction apparatus. At the time of his death, Callan was engaged in making a coil for Mr. Gassiot, the Vice-President of the Royal Society.

\section{$3 \quad$ Electric motors}

Callan's researches were inspired, one might say, by the motto 'Electricity in the Service of Man'. Being somewhat of a visionary, he sought to use electricity as a prime mover, and to this end, constructed motors driven by electricity obtained from his battery. Two of these are shown in Fig. 7. They were essentially simple in construction and operation [21]. The rotors consisted of a series of iron bars

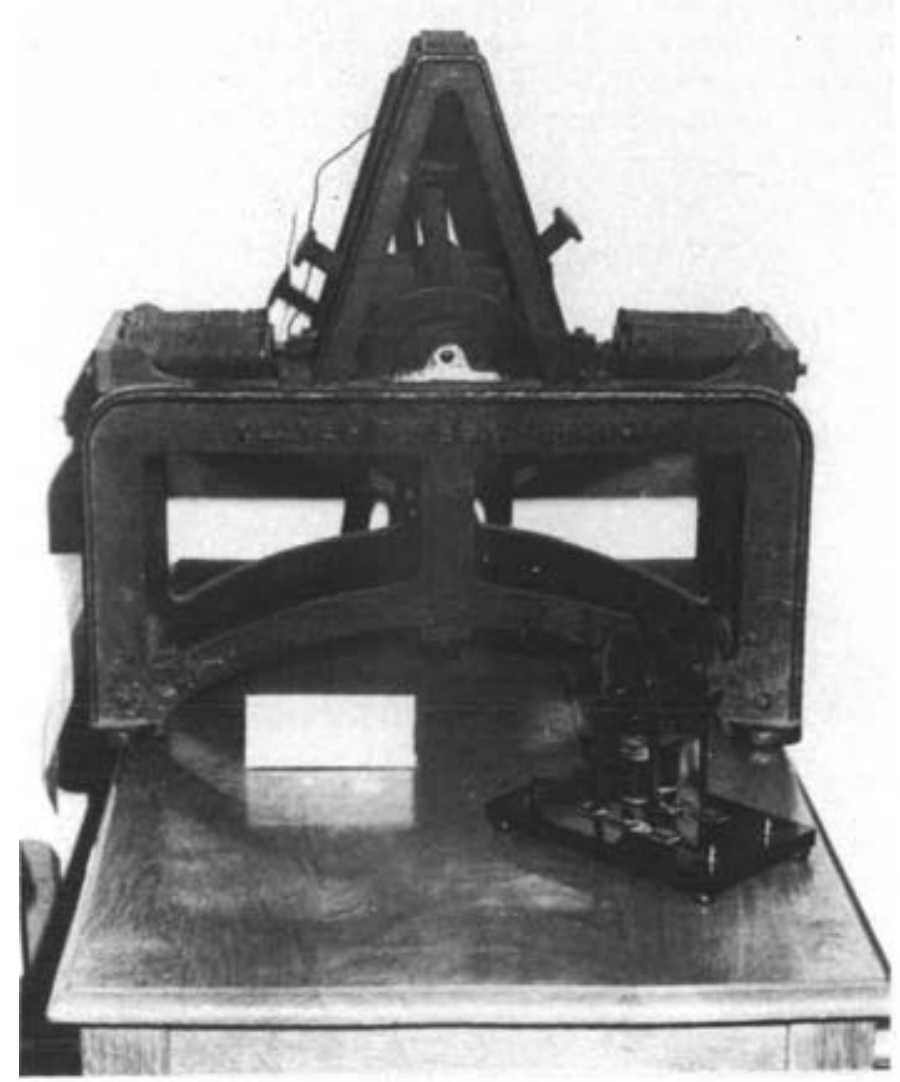

Fig. 7 Two of Callan's electric motors

[Photo. courtesy Irish Electricity Supply Board] 
or plates mounted on the periphery of a wheel. The end of the axle carried a small wheel with pointed teeth which made contact with a stationary spring strip. When this contact was made, the current flowed to energise the stationary electromagnets which attracted the bars. Just as the bars passed over the poles of the magnets the teeth lost contact with the strip and the current was interrupted. The momentum kept the machine rotating until the next tooth made contact when the process was repeated. The small motor of Fig. 7 has one set of electromagnets, but the large model has four sets mounted on a metal frame. The rotor had an axle carrying eight arms or spokes, to the ends of which were attached the iron plates. He experimented with a number of motors of this type, and had hopes of using them to electrify the railway line from Dublin to Dun Laoghaire (formerly Kingstown). He estimated that an electric motor as powerful as the steam engines then in use could be built for $£ 250$. It would weigh less than two tons, and could be maintained at an annual cost of $£ 300$, which was a quarter of the cost of steam power [15]. He designed an engine intended to propel a carriage and load at a speed of eight miles an hour, but he met with a number of snags. The batteries were spillable and unwieldy; electromagnetic action is powerful only at a short distance, and large magnets interfere with one another. In time he learnt that laboratory scale tests do not always apply to large scale work, and in the end he was forced to abandon the idea.

In 1838 , whilst working with one of his electric motors, he was astonished to find, as he tells us:

'By moving with the hand some of the electromagnets, sparks are obtained from the wires coiled around them, even though the engine is in no way connected with the Voltaic battery. I do not know how to account for the sparks except by supposing that the motion of the iron bars excites in them a certain magnetic power by which an electric current is caused to flow in the wire coiled round it. When the bars are at rest, they do not exhibit any magnetic power whatsoever [17]'.

Rather intriguingly, the extract quoted above would seem to refer to 'moving the electromagnets by hand', thus implying, to the modern reader at least, the existence of a wound rotor as opposed to a simple construction of iron plates. The suggestion has been made that Callan had stumbled here upon the principle of self-excitation in the dynamo, thus anticipating the work of Siemens by some 29 years. However, there seem to be no remains of such a wound-rotor machine in existence; neither is there any evidence to suggest that field coils were energised by connection to the output of the machine. It seems most likely that the phenomenon he observed was a result of residual flux in the machine, the changing flux distribution caused by movement of the rotor giving rise to a small induced EMF in the stator windings. Callan himself reported that the resulting currents were very feeble, and certainly not of the magnitude which would have occurred had proper selfexcitation been present. Nevertheless, he had made the interesting observation that a machine which had been constructed as a motor could also behave as a generator, a discovery of some interest and importance at that early date.

The fact that the currents were so feeble probably discouraged him from following up the discovery, as at the time he was much more interested in producing large currents to drive his motors and coils. Also, excessive work led to a breakdown in his health entailing an interruption of his scientific studies and forcing him to take a long rest for the greater part of the period 1849 to 1851 .
A steady objective in Callan's research was the cheap production of electricity. At that time, of course, the dynamo had not been invented. Frictional machines produced electricity of great intensity, but useless to drive an electromagnet; in modern terms, it lacked amperage. Voltaic cells, on the other hand, (Voltaic circles in Callan's terminology) produced electricity in quantity, but not in intensity, although this could be increased by connecting cells in series. Callan experimented with the Wollaston cell, a zinc/copper/sulphuric-acid arrangement, and also with the 'improved' Woolaston cell, also known as the 'double copper' in which the copper plate had the shape of a ' $U$ ' with the zinc plate in the centre which effectively doubled the useful area of the zinc plate. Callan improved on this by using a copper container which acted as the positive plate, and thereby eliminated the cost of a porcelain or glass container and made the whole thing cheaper to construct.

It had been established for some years that the quantity of electricity from a Voltaic cell increased with the area of the plates, and the intensity with the number of cells in the battery. He set out to obtain large quantities of electricity, and his first step was to use plates of much greater area than usual. In a paper to Philosophical Magazine in 1836 he described 'a very large battery, lately constructed for the college at Maynooth' [13]. This consisted of $20 \mathrm{zinc}$ plates, each two feet square $\left(0.2 \mathrm{~m}^{2}\right)$, and twenty copper cells, each large enough to contain a zinc plate with clearances of about a quarter of an inch $(6.3 \mathrm{~mm})$ between zinc and copper surfaces. The plates were covered with woven nets of hemp to help prevent contact with the copper, and they were raised and lowered by means of a windlass. It required nearly thirty gallons (135 l) of acid to fill the whole battery. All the zinc and all the copper plates were joined together so as to give a total effective surface area of 160 square feet $\left(14.72 \mathrm{~m}^{2}\right)$. He experimented with these cells in various series/parallel arrangements, and to this end devised his own method of interconnection. He used wooden boards having grooves cut into them, these being filled with mercury. By means of these boards he was able to connect all twenty in parallel, or to have various other series/parallel arrangements.

According to Callan: 'So enormous is the quantity of electricity circulated by this battery when all the zinc and copper plates act as a single circle, that on one occasion, after having acted without interruption for more than an hour, it rendered powerfully magnetic an electromagnet on which were coiled 39 thick copper wires. . . . On the fifth day it was tried: after having been in action without interruption for more than two hours this battery melted very rapidly platina wire $1 / 30$ th of an inch thick, and deflagrated in a most brilliant manner copper and iron wire about $1 / 12$ th of an inch thick'.

He experimented with various other types of cell. The Poggendorf dichromate cell he found to be wasteful of zinc, although it gave steady currents over a period of time. The Daniell cell was found to be more economical of zinc, but had a higher internal resistance. The Grove cell used a platinum plate which, even in those days, was prohibitively expensive. The Bunsen cell, which was a modification of the Grove cell using carbon plates or blocks in place of the platinum, was found to evolve most disagreeable fumes of nitrogen peroxide at the carbon pole, besides which there were considerable difficulties in making good contact between the carbon and copper wires. Some of these cells which are still at Maynooth have been found to 
contain traces of ammonium chloride, indicating that he had been experimenting with the use of this substance as an electrolyte. This implies that he had been using what later became known as the Leclanché type of cell, the sort still used in today's dry batteries.

In 1847 he published in Philosophical Magazine [22] a paper entitled 'On a new voltaic battery, cheap in its construction and use and more powerful than any battery yet made, and also on a cheap substitute for nitric acid of the Grove's platinum battery'. From this paper it is clear that Callan's invention of the cast-iron battery was the result of his experiments with the Grove cell. He first substituted lead for the platinum. Although the platinum cell was initially twice as strong as the lead cell, at the end of three and a half hours the lead was twice as strong as the platinum. Some days later he compared their powers by using them to energise an electromagnet, and he found that the lead one had greater lifting power than the platinum. To quote his own words 'these tests also showed that the power of the leaden battery was evidently superior to the platinum one'. He also studied other metals with a view to finding a cheaper alternative for platinum, but he found that with the single exception of cast iron, they were all inferior to it. Nitric acid, the fluid used in these cells, was very expensive and also attacked the gilding and platinising which he sometimes used on the lead plates. He found that by adding nitre (potassium nitrate) to sulphuric acid and diluting it with an equal volume of water he got a much cheaper mixture which was even better than that using the concentrated acid. He also tried to avoid the use of sulphuric acid by substituting various sulphates, but he was unsuccessful.

He now applied to the Trustees of the College for permission to convert the existing Wollaston batteries into cast-iron ones. He decided that, instead of using plates, he would use containers made of cast iron with zinc plates. The zinc plate was contained in a porous pot inside the cast-iron container, and it was filled with a sulphuric-acid/ nitre mixture. He built a total of 577 of these cells, with a combined area of zinc of some 96 square feet $\left(9 \mathrm{~m}^{2}\right)$ [23]. Sixteen gallons (73 l) of sulphuric acid and fourteen gallons (64 l) of nitric acid were required [19]. He 'abstained from using the solution of nitre through an apprehension that it would cause the exciting mixture to boil over'. This was reckoned to be the world's largest battery at the time, being at least twice as large as that constructed at the École Polytechnique on Napoleon's orders. Cells of this sort were subsequently manufactured by E.M. Clarke at the Adelaide Gallery of Practical Science, 428, The Strand, London, and one of these can be seen in Fig. 8. On 7th March 1848, before a large audience in the college, Callan demonstrated the power of his battery. A five-inch $(13 \mathrm{~cm})$ arc of blinding light was caused to appear between brass and copper terminals, and a large turkey placed in the circuit was instantly electrocuted!

'The shock was administered through two pieces of tinfoil four inches square under each wing along the sides of the turkey, previously stripped of feathers and moistened with dilute acid'.

On application of the shock, 'the craw of the turkey was burst and the hay and oats contained within it fell to the ground'

'The person who held the turkey had a very thick cloth between each hand and the wing to save him from the shock': which was just as well!

In his choice of cast iron, Callan had been influenced by the fact that cast iron withstood the action of nitric acid almost as well as platinum or gold and was, of course, much cheaper. As a result of his investigations into the

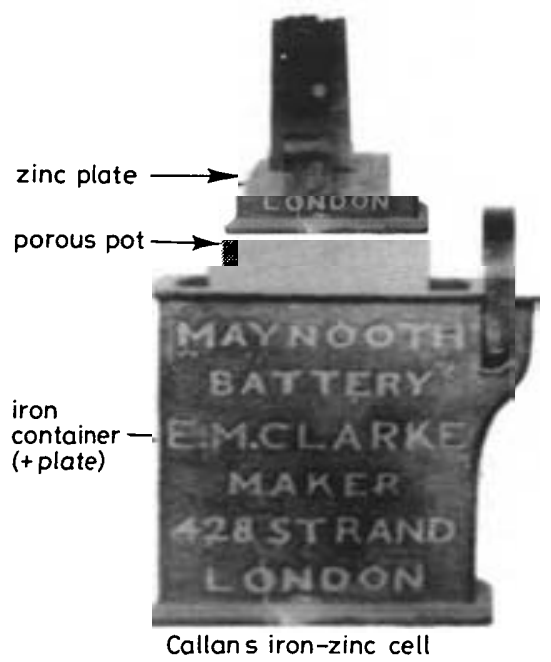

Fig. 8 Cell from the Maynooth cast-iron battery

corrosion of the iron, he discovered that iron coated with a mixture of lead and tin was much more resistant to attack than iron coated with zinc alone as in the more usual galvanising process. The addition of a little zinc to the lead/ tin mixture hardened the coating, but reduced its resistance to corrosion. The addition of a little antimony, on the other hand, was a great improvement. He concluded that this coating would 'probably answer for vitriol chambers better than lead'. He patented this process in 1853 [24, 25], and Maynooth College still possesses the elaborate patent document bearing the seal of Queen Victoria. The patent was entitled 'A means of protecting iron of every kind against the action of the weather and of various corroding substances so that iron thus protected will answer for roofing, cisterns, baths, gutters, pipes, window-frames, telegraph-wires for marine and various other purposes'.

\section{Summary}

We have now described what might be called the main themes of Callan's electrical researches, but he pursued other investigations too. As we have seen, he used to measure the currents supplied by his batteries by the lifting power of electromagnets and by the heating effects produced, but he also devised a type of galvanometer [25] which was later widely used by Stewart and Magee, and is sometimes called by their names. Callan also experimented with various forms of electric lighting, from arc lights to limelights. By electrolysing acidulated water he produced hydrogen and oxygen [25] which gave him an oxyhydrogen torch with which he heated up a block of lime, producing an intensely brilliant light. He hoped that this would serve for lighthouse beacons, but practical difficulties militated against its use. Hydrogen and oxygen, after all, can form a highly explosive mixture; Callan described one occasion on which an explosion shattered the vessel in which the gases were contained. Fortunately he was unhurt.

Another interesting device was Callan's point-and-plate valve [26]. He seems to have discovered that the secondary voltage from his induction coil was alternating in direction. One can only surmise how he ascertained this fact; perhaps he tried to electrolyse acidulated water with this voltage and found that no electrolytic products were obtained. From the fact that current was obviously 
flowing, but was creating no effect, this could only have meant that it was flowing alternately in opposite directions. He discovered, or found by chance, that if he interposed a plate and point spark-gap in the circuit, it behaved in an asymmetrical manner as far as the flow of current across the gap was concerned. This device, the first simple rectifier, was later used in the earliest X-ray apparatus.

Apart from all this scientific activity, there is another aspect of this quaint old savant which must be mentioned in order to get a complete picture of the man, and that is his boundless charity and love of the poor. His researches in the laboratory did not interfere with his efforts to alleviate their sufferings. He translated the works of St. Alphonso Liguori and gave the proceeds of their sale to charity. The Dundalk Democrat said on 16th January 1864 [27], a few days after his death: 'His charities were, considering his means, munificent. In seasons of distress he devoted to this purpose his whole salary as Professor and at all times denied himself many personal comforts that he might have more to give to the poor. ... His extraordinary piety, his perfect simplicity and unaffected candour endeared him to everyone who knew him. For many years he was regarded by both Professors and Students of Maynooth with a reverence and affection that could scarcely be understood by those who did not witness his daily life and they all deplore his death as an irreparable loss to the college, which at once he edified by his knowledge and adorned by his learning.'

In 1964, the centenary of Callan's death, celebrations were held at Maynooth and a memorial tablet was placed in the modern lecture theatre which occupies the site of Callan's lecture theatre and laboratory. The lecture theatre itself was formally named the Callan Hall. A special session of the Royal Irish Academy was held to honour the centenary, the President of Ireland, Dr. Eamonn de Valera, being present. The Institute for Industrial Research and Standards in Dublin has named a laboratory in his honour, and in October 1981 the Cardinal Archbishop of Armagh unveiled a special plaque in the library of the Regional Technical College at Dundalk, the town where he received his primary education.

In 1983 the Irish Branch of the Institution of Electrical Engineers sponsored a 'Callan Medal' to be awarded annually to the student who presents the best electrical project at the 'Young Scientists' Exhibition' which is held every January in the Royal Dublin Society's premises at Ballsbridge, Dublin.

\section{References}

1 McLaUghlin, P.J.: 'Nicholas Callan, Priest Scientist 1799-1864' (Clonmore Reynolds, Dublin, 1965)

2 McLAUGHLIN, P.J.: 'Some Irish contemporaries of Faraday and Henry', Proc. Roy. Irish Acad., 1964, 64, section A, pp. 17-35

3 Gallivan, J.D.: 'Science in schools', Nature, 1957, 180, pp. 730-732
4 CALlAN, N.J.: 'On the electrodynamic induction machine'. British Association Report, Dublin, 1857, Pt. 2 pp. 11-13

5 CALlAN, N.J.: 'On the induction apparatus', Phil. Mag., 1857, 14, (4th series), pp. 323-340

6 FLEMING, J.A.: 'The alternating current transformer in theory and practice'. ((Electrician Publishing Co. 1889/92) 2, p. 7

7 FLEMING, J.A.: 'Induction coil', in 'Encyclopaedia Britannica'. (11th Edition, Cambridge University Press, 1910), 14, pp. 502-505

8 STURGEON, W.: 'Improved electromagnetic apparatus', Trans. Soc. for Encouragement of Arts, Manufactures and Commerce, 1825, 43, pp. $37 \mathrm{ff}$

9 WHITE, F.: Letter in Penny Mechanic and Chemist, 1839, 4, no. 17 (new series), no. 139 (old series), p. 136

10 REINGOLD, N. (Ed.): 'The papers of Joseph Henry'. (Smithsonian Institution Press, Washington)

11 POST, R.C.: 'Physics, patents and politics - a biography of Charles Grafton Page'. (Science History Publications, New York, 1976)

12 CALLAN, N.J.: 'On the best method of making an electromagnet for electrical purposes and on the vast superiority of the electric power of the electromagnet over the electric power of the common magnetoelectric machine', Sturgeon's Annals of Electricity, 1836-7, 1, pp. 295-302

13 CALlaN, N.J.: 'On a new Galvanic battery', Phil. Mag., 1836, 9 (series 3), pp. 472-478

14 CALLAN, N.J.: 'A description of an electromagnetic repeater, or of a machine by which the connection between the voltaic battery and the helix of an electromagnet may be broken and renewed several thousand times in the space of one minute', Sturgeon's Annals of Electricity, 1836-7, 1, pp. 229-230

15 CALLAN, N.J.: 'On a method of connecting electromagnets so as to combine their electric powers and on the application of electromagnetism to the working of machines', Sturgeon's Annals of Electricity, 1836-7, 1, pp. 491-494

16 FIZEAU, H.L.: 'Notes sur les machines électriques inductives et sur la moyen facile d'accroître leurs effets', Comptes Rendus Acad. Sci. Paris., 1853, 36, pp. 418-421

17 CALLAN, N.J.: Letter in Sturgeon's Annals of Electricity, 1838, 2, pp. 317-318

18 BACHHOFFNER, G.H.: 'On the electromagnetic machine', Sturgeon's Annals of Electricity, 1838, 2, pp. 207-213

19 FLEMING, J.A.: 'The historical development of the induction coil and transformer', Electrician, 1891, 26, pp. 396-397, 416-417. ibid., 1892 , 27, pp. 211-213, 146-148, 300-302, 359-361, 433-435 (see page 212 in particular)

20 MOLLOY, G.: 'The induction coil and Dr. Callan of Maynooth College', Electrician, 1891, 26, p. 465

21 CALLAN, N.J.: 'A description of the most powerful electromagnet yet constructed', Sturgeon's Annals of Electricity, 1836-7, 1, pp. 376-378

22 CALLAN, N.J.: 'On a new Voltaic battery, cheap in its construction and use and more powerful than any yet made. And also a cheap substitute for nitric acid in the Grove platina battery', Phil. Mag., 1847, 31 (3rd series), pp. 81-85

23 CALLAN, N.J.: 'On the construction and power of a new Galvanic battery', Phil. Mag., 1848, 33 (3rd series), pp. 49-53

24 CALLAN, N.J.: 'A means of protecting iron of every kind against the action of the weather and of various corroding substances so that iron thus protected will answer for roofing, cisterns, baths, gutters, pipes, window-frames, telegraph-wires for marine and various other purposes'. British Patent 2340, 1853

25 CALLAN, N.J.: 'On the results of a series of experiments on the decomposition of water by the Galvanic battery with a view to obtain a constant brilliant lime-light', Phil. Mag., 1854, 7 (4th series), pp. 73-97

26 CALLAN, N.J.: 'On an induction coil of great power and on the effects of connecting plates with the ends of the secondary coil', ibid., 1863,25 (4th series), pp. 413-417

27 Obituary, Dundalk Democrat, 16th January 1864 